\title{
EFFECT OF SOURCE AND LEVEL OF DIETARY WATER HYACINTH ON NILE TILAPIA, Oreochromis niloticus, PERFORMANCE \\ Abdelhamid, A.M. ${ }^{1}$; F.I.Magouz ${ }^{2}$; M. I. B. El-Mezaien ${ }^{2}$; M.M. El-S. Khlafallah $^{2}$ and E. M. O. Ahmed ${ }^{2}$ \\ 1- Anim. Prod. Dept., Fac. of Agric., Al-Mansoura Univ. and \\ 2- Anim. Prod. Dept., Fac. of Agric., Kafr El-Sheikh Univ., Egypt
}

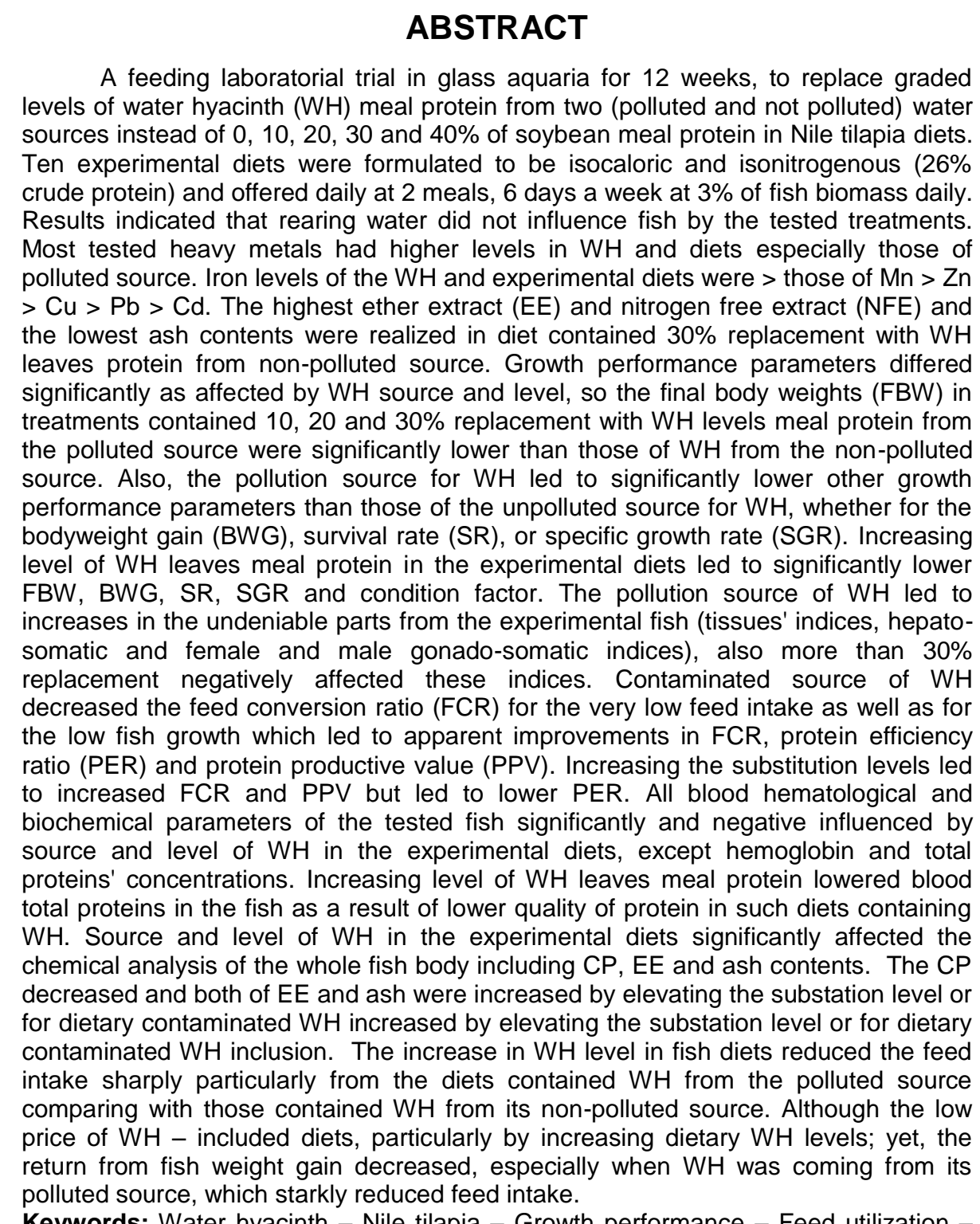

Keywords: Water hyacinth - Nile tilapia - Growth performance - Feed utilization Economic evaluation. 


\section{INTRODUCTION}

Tilapia is the third largest group of farmed finfish species, only after carps $\left(10.37 \times 10^{6} \mathrm{mt}\right)$ and salmonids $\left(0.94 \times 10^{6} \mathrm{mt}\right)(\mathrm{FAO}, 1997)$, with an average annual growth rate of about $11.5 \%$. In addition, Nile tilapia was the $6^{\text {th }}$ most cultured finfish species in the world in 1995 with a total production of $473,641 \mathrm{mt}$ with an average compound growth rate of about $12 \%$ per annum since 1986. The global production of farmed tilapia has increased more than three-folds since 1984, from $186.544 \mathrm{mt}$ to $659.000 \mathrm{mt}$, representing $4.48 \%$ of total farmed finfish in 1995, with a value of US\$ 925 million (Tacon, 1997). About $650.000 \mathrm{mt}$ or $98.6 \%$ of farmed tilapia were produced in developing countries in 1995, where Asia alone produced about $84 \%$ of this amount (FAO, 1997). EL-Sayed (2006) mentioned that Egypt produced $20 \%$ of the world tilapia capture and $12 \%$ of the world farmed tilapia. Recently, Bakeer (2009) cited that tilapia fish are among the ancient Egyptian fish of origin; yet, they became among the most outspreading fish species all over the world. They are cultured nowadays world wide, so their production exceeded 2.5 million tons year 2006, and Egypt now take the $2^{\text {nd }}$ position after China in the world production and the $1^{\text {st }}$ in Africa and middle East. He added that the local fish production is more than one million ton, from which the fish culture is about $63 \%$ (630 thousand tons) year 2007. About $80 \%$ of the culture production is tilapia (504 thousand tons).

Water hyacinth (Eichhorinia crassipes, Mart Solms) is a warm water aquatic plant which widespread in many countries, particularly during summer months with its highest growth in July (Sivakami and Ayyappan, 1991). ElSayed (2003) evaluated the effects of different fermentation methods on the nutritive value of water hyacinth $(\mathrm{WH})$ for Nile tilapia fingerlings. Fresh dry hyacinth (FH), molasses - fermented hyacinth (MF), cow rumen content fermented hyacinth (RF) and yeast - fermented hyacinth (YF) were incorporated into nine isonitrogenous $(35 \% \mathrm{CP})$, isocaloric $(450 \mathrm{kcal}$ $\mathrm{GE} / 100 \mathrm{~g}$ ) test diets as a replacement of dietary wheat bran at 10 and $20 \%$ substitution levels. These results indicate that fermentation of $\mathrm{WH}$ way only be necessary when incorporated into Nile tilapia diets at $20 \%$ inclusion levels. El-Sayed (2003) showed that, the fermentation of water hyacinth only be necessary when incorporated into Nile tilapia diets at $20 \%$ inclusion levels.

To be environmentally friends as well as to overcome the fish culture main problem of aqua feed shortage, an attention may be gifted to use this weed "water hyacinth" in fish feeding. So, the aim of this thesis was to evaluate the possibility of feeding Nile tilapia fish for 12 weeks on graded levels of replacing soybean meal protein with water hyacinth leaves meal protein. The evaluation was carried out via studying the quality criteria of fish rearing water, growth performance and survival of fish, feed and nutrients utilization, blood picture, chemical composition and economic evaluation.

\section{MATERIALS AND METHODS}

An in-door feeding experiment was conducted for 12 weeks to study the effect of replacing soybean meal protein by $0,10,20,30$ and $40 \%$ water hyacinth (Eichhorinia crassipes) protein from two sources, either from clean 
water or from polluted water, on growth performance, feed utilization, body composition, some blood parameters and preliminary economical evaluation of Nile tilapia (Oreochromis niloticus) fingerlings breeding.

Source of water hyacinth:

Water hyacinth was collected from two sources, the first source was from clean water (chanel) of the River Nile at Kafr El-Zayat. The second source was from polluted water (ditch) collected from a canal at Tanta, Manshiet Ganzor. The roots were removed and the rest of the plants were washed with running tap water to minimize the soil contamination, then dried under sunlight, and stored at room temperature until be used.

Experimaental fish:

The experimental fish (Oreochromis niloticus) were taken from the stock of Fish Research Laboratory in the Animal Production Department, Faculty of Agriculture, Kafrel-Sheikh University during January 2005. Prior to the start of the experiment, the fingerlings were placed in a fiberglass tank and randomly distributed into the experimental aquaria to be adapted to the experimental conditions until the start of the experiment. Fish were fed a control diet (without water hyacinth) for two weeks at a feeding level of $3 \%$ from the body biomass; during this period, healthy fish at the same weight replaced the died ones.

\section{Experimental design of rearing fish:}

A total number of 360 fish with $12.4 \mathrm{~g}$ average initial body weight were randomly distributed into 30 glass aquaria ( $70 \mathrm{~L}$ each, 12 fish in each). Each treatment was represented in three aquaria. Fresh tap water was stored in fiberglass tanks for $24 \mathrm{~h}$ under aeration for dechlorination. One third of water aquaria was replaced daily and totally once every week after removing the wastes. The experimental aquaria were supplied with air by electerical small pumps and air stones. During the experimental period (12 weeks), each aquarium was suppled with electric heater and the water temperature was maintained on $26 \pm 1^{\circ} \mathrm{C}$ through the thermostat. Photoperiod was controlled to be $14 \mathrm{~h}$ per day using florescent light. Fish feces and feed residue were removed daily by siphoning.

\section{Experimental diets and feeding regime:}

Prior to the start of the experiment, the fishes were adapted to a basal control diet $\left(T_{1}\right.$, Table 1) containing about $26 \%$ crude protein and consisted of fish meal, soybean meal, yellow corn, wheat bran, sunflower oil and vitamin and minerals mixture for two weeks. Ten experimental diets were formulated from a basal diet to contain two sources of dried water hyacinth at a level of $0,10,20,30$ and $40 \%$ of soybean meal protein (diets No. 1, 2, 3, 4 and 5), respectively (from unpolluted water) and $0,10,20,30$ and $40 \%$ of soybean meal protein (diets No. 6, 7, 8, 9 and 10), respectively (from polluted water) as shown in Table (1). A basal diet was made from the commercial ingredients. The dry ingredients were finely ground and mixed by a dough mixer for 20 minutes for homogeneity. Oil was gradually added during the mixing. After homogenous mixture was obtained, forty $\mathrm{ml}$ water per hundred $\mathrm{g}$ diet was slowly added to the mixture. The diets were cooked on a water evaporator for 20 minutes. The diets were pelleted $(3 \mathrm{~mm})$ through fodder machine and the manufacture pellets were dried in a drying oven at $70^{\circ} \mathrm{C}$ for 


\section{Abdelhamid, A.M. et al.}

48 hours. The diets were collected, tagged and stored in refrigerator at $4^{\circ} \mathrm{C}$. Fish in all treatments were daily fed the experimental diets at a level of $3 \%$ of the fish biomass then weighed every week; accordingly, the amount of food (which was given twice daily at 8.0 a.m. and 3.0 p.m., six days a week for 12 weeks) was recalculated.

Table (1): Composition of the experimental diets.

\begin{tabular}{|l|c|c|c|c|c|c|c|c|c|c|}
\hline \multirow{3}{*}{ Ingredients } & \multicolumn{4}{|c|}{$\begin{array}{c}\text { Water hyacinth } \\
\text { (clean water source) }\end{array}$} & \multicolumn{4}{c|}{$\begin{array}{c}\text { Water hyacinth } \\
\text { (polluted water source) }\end{array}$} \\
\cline { 2 - 11 } & $\begin{array}{c}\mathbf{T}_{\mathbf{1}} \\
\mathbf{( 0 \% )}\end{array}$ & $\begin{array}{c}\mathbf{T}_{\mathbf{2}} \\
\mathbf{( 1 0 \% )}\end{array}$ & $\begin{array}{c}\mathbf{T}_{\mathbf{3}} \\
\mathbf{( 2 0 \% )}\end{array}$ & $\begin{array}{c}\mathbf{T}_{\mathbf{4}} \\
\mathbf{( 3 0 \% )}\end{array}$ & $\begin{array}{c}\mathbf{T}_{\mathbf{5}} \\
\mathbf{( 4 0 \% )}\end{array}$ & $\begin{array}{c}\mathbf{T}_{\mathbf{6}} \\
\mathbf{( 0 \% )}\end{array}$ & $\begin{array}{c}\mathbf{T}_{\mathbf{7}} \\
\mathbf{( 1 0 \% )}\end{array}$ & $\begin{array}{c}\mathbf{T}_{\mathbf{8}} \\
\mathbf{( 2 0 \% )}\end{array}$ & $\begin{array}{c}\mathbf{T}_{\mathbf{9}} \\
\mathbf{( 3 0 \% )}\end{array}$ & $\begin{array}{c}\mathbf{T}_{\mathbf{1 0}} \\
\mathbf{( 4 0 \% )}\end{array}$ \\
\hline Fish meal & 10 & 10 & 10 & 10 & 10 & 10 & 10 & 10 & 10 & 10 \\
\hline Soybean meal & 34.0 & 30.6 & 27.2 & 23.8 & 20.4 & 34.0 & 30.6 & 27.2 & 23.8 & 20.4 \\
\hline Yellow corn & 41 & 36.23 & 31.46 & 26.68 & 21.92 & 41 & 36.23 & 31.46 & 26.68 & 21.92 \\
\hline Wheat bran & 10 & 10 & 10 & 10 & 10 & 10 & 10 & 10 & 10 & 10 \\
\hline Sunflower oil & 4.9 & 4.9 & 4.9 & 4.9 & 4.9 & 4.9 & 4.9 & 4.9 & 4.9 & 4.9 \\
\hline $\begin{array}{l}\text { Vit. and Min. } \\
\text { premix* }\end{array}$ & 0.1 & 0.1 & 0.1 & 0.1 & 0.1 & 0.1 & 0.1 & 0.1 & 0.1 & 0.1 \\
\hline Water hyacinth & 0 & 8.17 & 16.34 & 24.52 & 32.68 & 0 & 8.17 & 16.34 & 24.52 & 32.68 \\
\hline Total & 100 & 100 & 100 & 100 & 100 & 100 & 100 & 100 & 100 & 100 \\
\hline
\end{tabular}

\section{Water quality parameters:}

Samples of water were taken from each aquarium daily to determine the values of $\mathrm{pH}$, dissolved oxygen concentration and water temperature. The $\mathrm{pH}$ value of water was determined daily by using an electrical digital $\mathrm{pH}$ meter. Concentrations of dissolved oxygen were measureed by using oxygen meter model 9060 . Water temperature was determined by using a mercuric Celsius thermometer.

Chemical analysis:

Chemical analysis of ingredients, diets and fish samples were analyzed according to A.O.A.C. (1990) for dry matter, crude protein, ether extract, and ash. Gross energy contents of the ingredients, experimental diets and fish samples were calculated by using the energy values of protein, lipid and carbohydrates presented in NRC (1993), being 5.65, 9.45 and $4.22 \mathrm{kcal} / \mathrm{g}$, respectively. Mineral analysis was carried out in the Chemical Analyses Lab., Regional Center, belonging to the General Authority for the Agricultural Budget Box, Ministry of Agriculture, Dokki, Giza.

Measurements of growth and feed utilization parameters:

Body weight of fish in each aquarium was measured at start and every week and total body length was measured at start, at 6th and 12th weeks during the experimental period (12 weeks). Growth parameters were average weight gain (AWG), average daily gain (ADG), total body length gain (TLG), relative growth rate \% (RGR), specific growth rate \%/day (SGR) and survival rate \% (SR). Feed conversion ratio (FCR), protein efficiency ratio (PER) and 
protein productive value \% (PPV), were estimated at the end of the experimental period according to the equations given by Abdelhamid (2009a).

\section{Organs indices:}

All fish were killed at the end of the experiment, liver and gonads were removed and individually weighted. Hepatic somatic index (HSI) and gonado somatoc index (GSI) were calculated as described by Jangaard et al. (1967), Alabaster and Lioyed (1982), Tseng and Chan (1982) and Abdelhamid et al. ( 2004-a and b), respectively.

\section{Blood Samples:}

Blood samples were collected at the end of the experiment, fish in each aquarium were weighed and 5 fish were taken randomy for blood sampling. Blood samples were received in plastic tubes. Blood serum was isolated by centrifugation for 20 minutes at $4000 \mathrm{rpm}$. Serum samples were kept in deep freezer till the chemical analysis. Red blood cells $\left(\mathrm{RBC}_{\mathrm{s}} \times 10^{6} / \mathrm{mm}\right)$, platelets and white blood cells $\left(\mathrm{WBC}_{\mathrm{s}} \times 10^{3} / \mathrm{mm}\right)$ were counted by using a haemocytometer. Hemoglobin was determined using commercial colorimetric kit (Diamond Diagnostic, Egypt). Blood serum biochemical constituents were determined calorimetrically using commercial kits produced by Diagnostic System Laboratories, INC, USA. Total protein was determined as described by Tietz (1990). Albumin was determined according to Doumas et al. (1971). The concentration of serum globulin was obtained by subtracting the albumin from the total blood serum proteins concentration. Serum cholesterol was carried out according to the method described by Trinder (1969). Serum total lipids was determined according to the method of McGowan et al. (1983). Serum creatinine was estimated according to the method of Tietz (1986). Blood serum urea was determined according to Patton and Grouch (1977). Activity of alanin amino transferase (ALT) and activity of asparatate transferase (AST) were determined by the methods of Young (1990).

\section{Economical evaluation:}

Preliminary economical evaluation of the experimental diets has been calculated based on the cost of one $\mathrm{kg}$ fish weight gain produced (LE), using feed conversion rate and the price of the experimental diets. Costs were the price of feeds in local markets during 2005. Costs of $1 \mathrm{~kg}$ of fish meal, soybean meal, wheat bran, yellow corn, sunflower oil, vitamins and minerals premix, were $3.0,1.5,0.70,1.0,3.5$, and 4 LE, respectively.

\section{Statistical analysis:}

The obtained numerical data were statistically analyzed using SAS (1996) for one-way analysis of variance. Differences between comparisons among treatment means were made by using Duncan multiple range test (Duncan, 1955).

\section{RESULTS AND DISCUSSION}

\section{Water quality criteria:}

Table (2) illustrates some quality criteria measured in the fish rearing water as means (of the experimental whole period) for different experimental treatments (replacing levels by water hyacinth whether from clean or polluted 
origins). Water temperatures range $26.4-27.5^{\circ} \mathrm{C}, \mathrm{pH} 7.15-7.20$ and dissolved oxygen $5.01-5.30 \mathrm{mg} / \mathrm{l}$. These ranges are ideal for rearing Nile tilapia fish according to Abdelhamid (1994, 1996, 2009-a \& b).

Table (2): Averages of some physical and chemical parameters of fish rearing water during the feeding experimental period as affected by level and source of water hyacinth in the diets.

\begin{tabular}{|c|c|c|c|c|}
\hline Treatments & $\begin{array}{c}\text { Source of water } \\
\text { hyacinth }\end{array}$ & $\begin{array}{c}\text { Water temperature } \\
{ }^{\circ} \mathbf{C}\end{array}$ & Water $\mathbf{~ p H}$ & $\begin{array}{c}\text { Dissolved } \\
\text { oxygen } \mathbf{~ m g} / \mathbf{L}\end{array}$ \\
\hline \multirow{2}{*}{$\mathrm{T}_{1}$} & Clean water & 27.50 & 7.20 & 5.30 \\
\cline { 2 - 5 } & Polluted water & 27.50 & 7.20 & 5.30 \\
\hline \multirow{3}{*}{$\mathrm{T}_{2}$} & Clean water & 27.40 & 7.15 & 5.00 \\
\cline { 2 - 5 } & Polluted water & 27.45 & 7.20 & 5.01 \\
\hline \multirow{2}{*}{$\mathrm{T}_{3}$} & Clean water & 27.00 & 7.15 & 5.01 \\
\cline { 2 - 5 } & Polluted water & 26.45 & 7.15 & 5.01 \\
\hline \multirow{2}{*}{$\mathrm{T}_{4}$} & Clean water & 26.85 & 7.15 & 5.02 \\
\cline { 2 - 5 } & Polluted water & 27.00 & 7.20 & 5.02 \\
\hline \multirow{2}{*}{$\mathrm{T}_{5}$} & Clean water & 26.50 & 7.20 & 5.04 \\
\cline { 2 - 5 } & Polluted water & 26.40 & 7.15 & 5.02 \\
\hline
\end{tabular}

Trace and heavy metals:

Table (3) shows some trace elements and heavy metals of water hyacinth $(\mathrm{WH})$ and diets used in the tested fish feeding. From this Table, it is clear that most of these elements were higher in the WH from polluted source than from clean source by 1160.7, 193/1, 373.6, 246.9, 25.0, and $\alpha \%$ for Fe, $\mathrm{Mn}, \mathrm{Zn}, \mathrm{Cu}, \mathrm{Pb}$, and $\mathrm{Cd}$, respectively. This consequently elevated the same elements in the diets containing polluted $\mathrm{WH}$ than in those containing the clean $\mathrm{WH}$ by $2217.3 \%(\mathrm{Fe}), 221.8 \%(\mathrm{Mn}), 379.6 \%(\mathrm{Zn}), 181.0 \%(\mathrm{Cu}), 500 \%$ $(\mathrm{Pb})$ and $0.0 \%(\mathrm{Cd})$. However, the highest concentrations were for $\mathrm{Fe}>\mathrm{Mn}$ $>\mathrm{Zn}>\mathrm{Cu}>\mathrm{Pb}>\mathrm{Cd}$, whether in $\mathrm{WH}$ or in the experimental diets. In this context, Abdelhamid and Gabr (1991-b) obtained higher $\mathrm{Pb}$ and $\mathrm{Hg}$ concentrations in ditch - WH than in channel - WH. Water hyacinth plant differs in its heavy metal concentrations from one part of the plant to the other parts of the same plant, since its leaves contain more aluminum $(2.1 \%)$ than its steam $(1,5 \%)$. Yet, ferrous is more concentrated in steams $(0.354 \%)$ than in the leaves $(0.255 \%)$. So, $\mathrm{WH}$ is used in reducing heavy metals toxicity for its spongy like properties in adsorption and accumulation of what is in the attached environment (James et al., 1992).

Table (3): Chemical composition of some metals of water hyacinth and manufactured diets as affected by the dietary water hyacinth (WH) source.

\begin{tabular}{|c|c|c|c|c|c|c|c|}
\hline \multirow{2}{*}{ Items } & Source of & \multicolumn{7}{|c|}{ Minerals (ppm) } \\
\cline { 3 - 8 } water hyacinth & $\mathbf{F e}$ & Mn & $\mathbf{Z n}$ & $\mathbf{C u}$ & $\mathbf{P b}$ & $\mathbf{C d}$ \\
\hline Water hyacinth & Clean water & 305 & 96.6 & 10.6 & 3.2 & 0.4 & 0.00 \\
\cline { 2 - 8 }$($ WH) & Polluted water & 3540 & 186.5 & 39.6 & 7.9 & 0.1 & 0.01 \\
\hline $\begin{array}{c}\text { Diets including } \\
(\text { WH) }\end{array}$ & Clean water & 106.3 & 43.5 & 4.9 & 2.1 & 0.01 & 0.00 \\
\cline { 2 - 8 } & Polluted water & 2357 & 96.5 & 18.6 & 3.8 & 0.05 & 0.00 \\
\hline
\end{tabular}


However, aquatic plants are spongy-like, i.e. they absorb different elements and metals from the ambient water and accumulate them in their tissues (Abdelhamid, 2009-b).

Diets composition:

Table (4) presents routine analysis of the experimental diets. They were almost isonitogenous and isocaloric $(26.13-26.80 \%$ crude protein and 429 - $443 \mathrm{Kcal} \mathrm{GE} / 100 \mathrm{~g}$ dry matter, respectively). Yet, EE, NFE and ash ranges were $4.35-5.05 \%, 58.1-61.4 \%$ and $7.34-11.03 \%$, respectively. Treatment No. 4 containing clean WH was the highest in EE and NFE and the lowest in ash contents among all diets with different WH inclusion levels and sources. This is in agreement with the findings of Abdelhamid and Gabr (1991-a) who found that water hyacinth (WH) contains low organic matter although its crude protein content was high. Also, ash, $\mathrm{K}$, and cell wall fractions were high. Thus, its intake, digestibility, feeding values and $N$ balance were low. Its high $\mathrm{K}$ content affected negatively serum analysis, water balance and kidney function. So, it may be used as an ingredient but not solely in animal feeding. Also, Abdelhamid and Gabr (1991-b) reported that $\mathrm{WH}$ from the ditch reflected higher contents of ether extract, crude protein, ash, acid detergent fiber (ADF), acid detergent lignin (ADL), cellulose and silica whereas most of the minerals $(\mathrm{Ca}, \mathrm{P}, \mathrm{Pb}$ and $\mathrm{Hg})$ were lower than in $\mathrm{WH}$ from the chanel. The leaves contained more neutral detergent fiber (NDF), hemicelluloses, cellulose, total phenols and phenalic tannin, but stems were higher in $A D F$ and $A D L$ than leaves. $C a / P$ ratio was narrow in the whole plant than in leaves or stems. Digestibility of organic matter (in vitro gas production system, $58.4 \%$ ) was closely to the in vivo estimated value (59.5\%), although metabolizable energy was $6.35 \mathrm{MJ} / \mathrm{Kg} \mathrm{DM}$. They added that, inclusion of WH in the rations reduced feed intake. Digestibility and nutritive values decreased by increasing $\mathrm{WH}$ levels in the ration. They found also, that WH increased blood total protein, albumin, total lipids and cholesterol, and decreased creatinin, phospholipids, inorganic $\mathrm{P}$ and $\mathrm{Ca}$, so WH may not be offered as a sole feed but it could be replace up to $50 \%$ of the diet's concentrates. So, El-Sayed (1999) presented alternative dietary protein sources for tilapia with emphasis on aquatic plants.

Table (4): Chemical analysis of the experimental diets on dry matter basis (\%) and calculated ${ }^{\star}$ gross energy content (Kcal/ $100 \mathrm{~g}$ ) as affected by the dietary source and level of water hyacinth (WH).

\begin{tabular}{|c|c|c|c|c|c|c|c|c|c|c|c|c|}
\hline Treat. & \multicolumn{2}{|c|}{ DM } & \multicolumn{2}{c|}{ CP } & \multicolumn{2}{c|}{ EE } & \multicolumn{2}{c|}{ Ash } & \multicolumn{2}{c|}{ NEF } & \multicolumn{2}{c|}{ GE } \\
\hline $\begin{array}{c}\text { Source } \\
\text { of WH }\end{array}$ & $\mathbf{C}$ & $\mathbf{P}$ & $\mathbf{C}$ & $\mathbf{P}$ & $\mathbf{C}$ & $\mathbf{P}$ & $\mathbf{C}$ & $\mathbf{P}$ & $\mathbf{C}$ & $\mathbf{P}$ & $\mathbf{C}$ & $\mathbf{P}$ \\
\hline $\mathbf{T}_{\mathbf{1}}$ & 59.0 & 59.0 & 26.5 & 26.5 & 4.73 & 4.70 & 8.60 & 8.60 & 60.2 & 60.2 & 439 & 438 \\
\hline $\mathbf{T}_{\mathbf{2}}$ & 59.4 & 60.2 & 26.5 & 26.4 & 4.40 & 4.83 & 11.03 & 8.60 & 58.1 & 60.1 & 442 & 440 \\
\hline $\mathbf{T}_{\mathbf{3}}$ & 59.8 & 60.2 & 26.4 & 26.8 & 5.02 & 4.83 & 8.46 & 8.56 & 60.2 & 59.8 & 429 & 439 \\
\hline $\mathbf{T}_{\mathbf{4}}$ & 61.2 & 60.6 & 26.2 & 26.1 & 5.05 & 4.35 & 7.34 & 8.63 & 61.4 & 60.9 & 443 & 437 \\
\hline \multicolumn{1}{|c|}{$\mathbf{T}_{\mathbf{5}}$} & 66.7 & 59.4 & 26.4 & 26.3 & 4.98 & 4.70 & 7.72 & 7.90 & 60.9 & 61.1 & 442 & 441 \\
\hline
\end{tabular}


Also, El-Ebiary et al. (2004) recommended using WH at a level up to $50 \%$ of tilapia diets. Abdelwareth (2006) found that WH contains $34 \% \mathrm{CP}, 6 \% \mathrm{EE}$ and $6.5 \%$ crude fiber and recommended its use at $20-30 \%$ level from dietary fish meal for Nile tilapia. Moreover, El-Sayed (2006) referred to water hyacinth as unconventional feedstuff that can be used in semi-intensive culture of tilapia in Egypt. He gave its chemical composition as $21.1 \% \mathrm{CP}$, $1.0 \% \mathrm{EE}, 19.0 \% \mathrm{CF}, 18.2 \%$ ash and $40.7 \%$ NFE to be fed at $10-20 \%$ of the fish diet.

Growth performance:

From Tables (5 and 6), initial body weight of the tested fish did not differ between clean and polluted $\mathrm{WH}$ included diets nor among levels (treatments) of the WH in the fish diets. Yet, final body weight of $T_{2}, T_{3}$ and $\mathrm{T}_{4}$ polluted $\mathrm{WH}$ were significantly lower than those of clean $\mathrm{WH}$. Since polluted WH inclusion and increasing WH levels led to significantly lower final body weight, total body weight gain, average daily gain and survival rate. Also, specific growth rate (SGR) took the same trends, i.e. it decreased by elevating $\mathrm{WH}$ inclusion level in the fish diet as well as by polluted $\mathrm{WH}$ than clean WH source. Also, increasing WH dietary inclusion levels led to lower condition factor (K) (Table 7). In accordance with the present results, ElEbiary et al. (2004) reported lower growth performance parameters of Nile tilapia fry by increasing the level of replacement with WH to more than $50 \%$. Abdelhamid et al. (2006) came to the same conclusion, thus they recommended to use WH protein at a level up to $20 \%$ of soybean protein in a diet for feeding Nile tilapia fingerlings.

Table (5): Growth performance and survival rate/aquarium of the experimental fish throughout the experimental period as affected by the dietary level and source of water hyacinth (WH).

\begin{tabular}{|c|c|c|c|c|c|c|c|c|c|c|c|c|}
\hline \multirow{2}{*}{$\begin{array}{l}\text { Treat- } \\
\text { ment } \\
\text { Source } \\
\text { of WH }\end{array}$} & \multicolumn{2}{|c|}{$\begin{array}{c}\text { Initial weight } \\
\text { (g) }\end{array}$} & \multicolumn{2}{|c|}{$\begin{array}{c}\text { Final weight } \\
\text { (g) }\end{array}$} & \multicolumn{2}{|c|}{$\begin{array}{c}\text { Average total } \\
\text { weight gain } \\
\text { (g) }\end{array}$} & \multicolumn{2}{|c|}{$\begin{array}{c}\text { Average } \\
\text { daily gain } \\
\text { (g/ day) }\end{array}$} & \multicolumn{2}{|c|}{$\begin{array}{c}\text { SGR } \\
\text { (\%/day) }\end{array}$} & \multicolumn{2}{|c|}{$\begin{array}{c}\text { Survial rate } \\
(\%)\end{array}$} \\
\hline & $\begin{array}{l}\text { Clean } \\
\text { water }\end{array}$ & $\begin{array}{l}\text { Polluted } \\
\text { water }\end{array}$ & $\begin{array}{l}\text { Clean } \\
\text { water }\end{array}$ & $\begin{array}{l}\text { Polluted } \\
\text { water }\end{array}$ & $\begin{array}{l}\text { Clean } \\
\text { water }\end{array}$ & $\begin{array}{c}\text { Polluted } \\
\text { water }\end{array}$ & $\begin{array}{l}\text { Clean } \\
\text { water }\end{array}$ & $\begin{array}{c}\text { Polluted } \\
\text { water }\end{array}$ & $\begin{array}{l}\text { Clean } \\
\text { water }\end{array}$ & $\begin{array}{l}\text { Polluted } \\
\text { water }\end{array}$ & $\begin{array}{l}\text { Clean } \\
\text { water }\end{array}$ & \begin{tabular}{|c|} 
Polluted \\
water
\end{tabular} \\
\hline$T_{1}$ & 147.00 & 149.00 & $\underset{\mathrm{ab}}{187.33}$ & $\underset{a}{188.17}$ & $\underset{\mathrm{ab}}{40.33}$ & $\underset{a}{30.17}$ & $\begin{array}{c}0.42 \\
\mathrm{ab}\end{array}$ & $\begin{array}{c}0.41 \\
a\end{array}$ & 0.289 & 0.278 & $\underset{b}{83.00}$ & $\underset{b}{83.00}$ \\
\hline$T_{2}$ & 147.67 & 149.33 & $\underset{\mathrm{bA}}{184.00}$ & $\underset{\mathrm{bB}}{174.27}$ & $\underset{b A}{36.33}$ & $2 \underset{b B}{24.94}$ & $\underset{b A}{0.38}$ & 0.26 & 0.262 & 0.184 & $\begin{array}{c}100.0 \\
0^{\mathrm{a}}\end{array}$ & $\underset{a}{100.00}$ \\
\hline$T_{3}$ & 146.67 & 149.00 & $\underset{\mathrm{aA}}{188.00}$ & $\underset{\mathrm{bB}}{169.50}$ & $\underset{\mathrm{abA}}{41.33}$ & 20.50 & $\underset{\mathrm{abA}}{0.43}$ & 0.21 & 0.291 & 0.153 & $\begin{array}{c}97.33 \\
a\end{array}$ & $\underset{a}{94.33}$ \\
\hline $\mathbf{T}_{4}$ & 147.33 & 149.33 & $\underset{a}{189.67}$ & 170.00 & $\underset{a A}{42.34}$ & $\underset{b B}{20.67}$ & $\underset{\mathrm{aA}}{0.44}$ & 0.22 & 0.301 & 0.154 & $\underset{a}{97.00}$ & $\underset{a}{91.00}$ \\
\hline$T_{5}$ & 147.33 & 149.00 & $\underset{a}{175.33}$ & 175.00 & 28.00 & 26.00 & $\begin{array}{c}0.29 \\
c\end{array}$ & 0.27 & 0.207 & 0.191 & $\begin{array}{c}91.38 \\
\mathrm{abA}\end{array}$ & $8{ }_{b B}^{81.83}$ \\
\hline MSE* $^{\star}$ & 0.34 & 0.46 & 1.44 & 2.00 & 1.55 & 2.09 & 0.02 & 0.03 & - & - & 1.93 & 1.96 \\
\hline
\end{tabular}

$a, b$ and $c$ means in the same rows bearing different letters significantly at 0.05 level.

$A$ and $B$ means in the same columns bearing different letters differ significantly at 0.05 level.

* Mean square of error from the analysis of variance. 
Table (6): Average weight gain (g/fish) and average daily gain ( $\mathrm{mg} / \mathrm{fish}$ ) as affected by the dietary level and source of water hyacinth (WH).

\begin{tabular}{|c|c|c|c|c|}
\hline \multirow{2}{*}{ Treatment } & \multicolumn{2}{|c|}{ AWG (g/fish) } & \multicolumn{2}{c|}{ ADG (mg/fish) } \\
\cline { 2 - 5 } & Clean water & Polluted water & Clean water & Polluted water \\
\hline $\mathbf{T}_{1}$ & $0.5315^{\mathrm{B}}$ & $1.6810^{\mathrm{A}}$ & $5.7730^{\mathrm{aA}}$ & $0.8125^{\mathrm{ab}}$ \\
\hline $\mathbf{T}_{2}$ & $0.2881^{\mathrm{B}}$ & $0.8480^{\mathrm{A}}$ & $0.3001^{\mathrm{DB}}$ & $2.1455^{\mathrm{DA}}$ \\
\hline $\mathbf{T}_{3}$ & $0.1304^{\mathrm{B}}$ & $1.0398^{\mathrm{A}}$ & $0.8640^{\mathrm{ab}}$ & $0.9385^{\mathrm{C}}$ \\
\hline $\mathbf{T}_{4}$ & $0.0425^{\mathrm{B}}$ & $0.6738^{\mathrm{A}}$ & $1.2199^{\mathrm{a}}$ & $2.0439^{\mathrm{D}}$ \\
\hline $\mathbf{T}_{5}$ & $0.4384^{\mathrm{B}}$ & $1.8199^{\mathrm{A}}$ & $0.6561^{\mathrm{abB}}$ & $5.4847^{\mathrm{aA}}$ \\
\hline
\end{tabular}

Table (7): Data of fish final weight (g), total length (cm) and condition (K) factor at the end of the experimental period as affected by the dietary level and source of water hyacinth (WH).

\begin{tabular}{|c|c|c|c|c|c|c|}
\hline Treatment & \multicolumn{2}{|c|}{ Final weight } & \multicolumn{2}{c|}{ Total length (L) } & \multicolumn{2}{c|}{ K- factor } \\
\hline Source of WH & $\begin{array}{c}\text { Clean } \\
\text { water }\end{array}$ & $\begin{array}{c}\text { Polluted } \\
\text { water }\end{array}$ & $\begin{array}{c}\text { Clean } \\
\text { water }\end{array}$ & $\begin{array}{c}\text { Polluted } \\
\text { water }\end{array}$ & $\begin{array}{c}\text { Clean } \\
\text { water }\end{array}$ & $\begin{array}{c}\text { Polluted } \\
\text { water }\end{array}$ \\
\hline $\mathbf{T}_{\mathbf{1}}$ & 15.69 & 18.85 & 10.30 & 10.60 & 1.435 & 1.500 \\
\hline $\mathbf{T}_{\mathbf{2}}$ & 15.84 & 14.60 & 14.13 & 12.91 & 0.560 & 0.71 \\
\hline $\mathbf{T}_{\mathbf{3}}$ & 15.40 & 15.00 & 11.97 & 12.27 & 0.897 & 0.812 \\
\hline $\mathbf{T}_{\mathbf{4}}$ & 12.72 & 15.94 & 11.17 & 11.23 & 0.911 & 1.122 \\
\hline $\mathbf{T}_{\mathbf{5}}$ & 20.23 & 15.94 & 11.60 & 12.17 & 1.296 & 0.884 \\
\hline MSE $^{*}$ & 2.43 & 1.83 & 0.47 & 0.35 & 0.01 & 0.02 \\
\hline
\end{tabular}

a, $b$ and $c$ means in the same rows bearing different letters significantly at 0.05 level.

$A$ and $B$ means in the same columns bearing different letters differ significantly at 0.05 level.

* Mean square of error from the analysis of variance.

Internal organs' indices:

The polluted WH diets increased significantly the inedible parts, i.e. hepato-somatic index and gonado-somatic index of both females and males than the other source (clean) of WH (Table 8). Up to 30\% replacement improved these indices, but higher than $30 \%$ affected negatively these indices. However, Abdelhamid et al. (2006) reported that dietary WH inclusion did not significantly influence HSI nor GSI (in female) but there were significant differences among treatments concerning GSI (male).

Table (8): Effect of level and source of dietary water hyacinth (WH) on organs indices of fish at the end of the experiment.

\begin{tabular}{|c|c|c|c|c|c|c|}
\hline Treatment & \multicolumn{2}{|c|}{ HIS } & \multicolumn{2}{c|}{ GSI (Female) } & \multicolumn{2}{c|}{ GSI (Male) } \\
\hline Source of WH & $\begin{array}{c}\text { Clean } \\
\text { water }\end{array}$ & $\begin{array}{c}\text { Polluted } \\
\text { water }\end{array}$ & $\begin{array}{c}\text { Clean } \\
\text { water }\end{array}$ & $\begin{array}{c}\text { Polluted } \\
\text { water }\end{array}$ & $\begin{array}{c}\text { Clean } \\
\text { water }\end{array}$ & $\begin{array}{c}\text { Polluted } \\
\text { water }\end{array}$ \\
\hline $\mathbf{T}_{1}$ & $0.5315^{\mathrm{B}}$ & $1.6810^{\mathrm{A}}$ & $0.9075^{\mathrm{ab}}$ & $0.2153^{\mathrm{bB}}$ & $5.7730^{\mathrm{aA}}$ & $0.8125^{\mathrm{ab}}$ \\
\hline $\mathbf{T}_{\mathbf{2}}$ & $0.2881^{\mathrm{B}}$ & $0.8480^{\mathrm{A}}$ & $0.3341^{\mathrm{bB}}$ & $2.3058^{\mathrm{aA}}$ & $0.3001^{\mathrm{bB}}$ & $2.1455^{\mathrm{bA}}$ \\
\hline $\mathbf{T}_{3}$ & $0.1304^{\mathrm{B}}$ & $1.0398^{\mathrm{A}}$ & $0.5911^{\mathrm{b}}$ & $0.6083^{\mathrm{D}}$ & $0.8640^{\mathrm{ab}}$ & $0.9385^{\mathrm{C}}$ \\
\hline $\mathbf{T}_{4}$ & $0.0425^{\mathrm{B}}$ & $0.6738^{\mathrm{A}}$ & $1.4500^{\mathrm{ab}}$ & $1.3428^{\mathrm{ab}}$ & $1.2199^{\mathrm{a}}$ & $2.0439^{\mathrm{b}}$ \\
\hline $\mathbf{T}_{\mathbf{5}}$ & $0.4384^{\mathrm{B}}$ & $1.8199^{\mathrm{A}}$ & $0.7708^{\mathrm{ab}}$ & $0.2004^{\mathrm{D}}$ & $0.6561^{\mathrm{abB}}$ & $5.4847^{\mathrm{aA}}$ \\
\hline MSE $^{\star}$ & 0.19 & 0.21 & 0.17 & 0.24 & 0.34 & 0.48 \\
\hline
\end{tabular}

a, $b$ and $c$ means in the same rows bearing different letters significantly at 0.05 level. $A$ and $B$ means in the same columns bearing different letters differ significantly at 0.05 level.

* Mean square of error from the analysis of variance. 


\section{Feed conversion and protein utilization:}

Table (9) show that feed conversion ratio was lower on polluted-WH diets than on clean - WH diets throughout all dietary inclusion levels. This may be due to lower bodyweight gain in fish fed the polluted-WH diets (Table 7 ) as well as to very low feed intake (Table 13) resulting in apparently better feed conversion, protein efficiency ratio (PER), and protein productive value (PPV\%) as illustrated in Table (9). However, FCR and PPV\% increased and PER decreased by increasing level of $\mathrm{WH}$ replacement.

Table (9): Feed conversion ratio (FCR), protein efficiency ratio (PER), and protein productive value (PPV\%) throughout the entire period of the experiment as affected by the dietary level and source of water hyacinth (WH).

\begin{tabular}{|c|c|c|c|c|c|c|}
\hline Treatment & \multicolumn{2}{|c|}{ FCR } & \multicolumn{2}{c|}{ PER } & \multicolumn{2}{c|}{ PPV \% } \\
\hline $\begin{array}{c}\text { Source } \\
\text { of WH }\end{array}$ & $\begin{array}{c}\text { Clean } \\
\text { water }\end{array}$ & $\begin{array}{c}\text { Polluted } \\
\text { water }\end{array}$ & $\begin{array}{c}\text { Clean } \\
\text { water }\end{array}$ & $\begin{array}{c}\text { Polluted } \\
\text { water }\end{array}$ & $\begin{array}{c}\text { Clean } \\
\text { water }\end{array}$ & $\begin{array}{c}\text { Polluted } \\
\text { water }\end{array}$ \\
\hline $\mathbf{T}_{\mathbf{1}}$ & $2.76^{\mathrm{b}}$ & $0.85^{\mathrm{C}}$ & 1.39 & $4.50^{\mathrm{b}}$ & $22^{\mathrm{b}}$ & $22.09^{\mathrm{b}}$ \\
\hline $\mathbf{T}_{\mathbf{2}}$ & $3.60^{\mathrm{a}}$ & $1.53^{\mathrm{b}}$ & 1.06 & $2.51^{\mathrm{B}}$ & $31^{\mathrm{a}}$ & $42.84^{\mathrm{a}}$ \\
\hline $\mathbf{T}_{\mathbf{3}}$ & $3.00^{\mathrm{a}}$ & $1.79^{\mathrm{b}}$ & 1.27 & $2.14^{\mathrm{B}}$ & $28^{\mathrm{a}}$ & $22.50^{\mathrm{b}}$ \\
\hline $\mathbf{T}_{\mathbf{4}}$ & $2.93^{\mathrm{b}}$ & $1.78^{\mathrm{b}}$ & 1.31 & $2.13^{\mathrm{B}}$ & $27^{\mathrm{a}}$ & $34.36^{\mathrm{a}}$ \\
\hline $\mathbf{T}_{\mathbf{5}}$ & $3.92^{\mathrm{a}}$ & $1.28^{\mathrm{b}}$ & 0.97 & $2.98^{\mathrm{A}}$ & $23^{\mathrm{b}}$ & $20.22^{\mathrm{b}}$ \\
\hline
\end{tabular}

$a, b$ and $c$ means in the same rows bearing different letters differ significantly at 0.05 level. $A$ and $B$ means in the same columns bearing different letters differ significantly at 0.05 level.

In agreement with these results, El-Ebiary et al. (2004) registered that PPV and energy utilization by fish decreased by increasing the level of replacement with $\mathrm{WH}$ to more than $50 \%$. Thus, they recommended using $\mathrm{WH}$ at a level up to $50 \%$ of diets containing a mixture of fish meal and soybean meal for feeding Nile tilapia fingerlings. Moreover, Abdelhamid et al. (2006) mentioned that PPV and PER of fish were decreased by increasing the level of replacement with WH more than $20 \%$.

\section{Blood profile:}

Significant differences were recorded among treatments of both groups fed on diets included WH whether from clean or polluted sources, concerning all tested hematological and biochemical parameters, with one exception in Table 10 (total proteins) and Table 11 (hemoglobin). There was a general decreasing trend in values of uric acid, urea, total protein, albumin, globulin, cholesterol, hemoglobin, and red blood cells in the fish fed clean WH including diets, but there was a general increasing trend in levels of transaminases, white blood cells and platelets (Table 10). Similar trends were recorded in Table (11) except for uric acid, urea, and transaminases which took the opposite trend (decrease). In this context, increasing the plasma total protein indicates the improvement in the nutritional value of the diet. In the present investigation, total protein was lowest when fish fed a diet where $30 \%\left(T_{4}\right.$, Table 10$)$ or $40 \%\left(T_{5}\right.$, Table 11) of soybean meal protein were substituted by $\mathrm{WH}$ protein and this is due to inferior the protein quality of these diets. 
J. of Animal and Poultry Production, Vol. 1 (4), April, 2010

10

143 
Abdelhamid, A.M. et al.

11 
Generally, anemia causes lower $\mathrm{Hb}$ concentration and $\mathrm{RBC}_{\mathrm{s}}$ count; bacterial infection, acidosis, and leucosis lead to higher $\mathrm{WBC}_{\mathrm{s}}$ count; liver diseases are responsible for lower concentration of blood urea, uric acid, and proteins, as well as transaminases' activity; malabsorption syndrome is a causative for lower level of blood lipids; and not infrequently lower cholesterol concentrations are obtained in pernicious anemia (Merck, 1976 and Varley, 1978).

Fish body composition:

The chemical composition at the experimental begin was $26.07 \%$ dry matter, $54.30 \%$ crude protein, $9.0 \%$ fat and $14.0 \%$ ash, on DM basis. From Table (12) of the chemical analysis (\% dry matter basis) of the whole fish body at the end of the experiment, it is clear that both of WH sources and dietary inclusion levels affected significantly each of crude protein (CP), ether extract (EE) and ash contents. Where, CP decreased but EE and ash increased by elevating the substitution level and inclusion of polluted $\mathrm{WH}$. This refers to the bad feed utilization by increasing WH substituting level, particularly from polluted source, may be for its inclusion on some heavy metals and also may be attributed to the low DM content of the tested rations. Also to that WH contains saponin as a toxic substance, and ca. $45 \mathrm{Kg}$ of this aquatic plant could be converted into $1 \mathrm{Kg}$ of fish. Moreover, WH is rich in crude fiber and ash contents leading to low nutritive value (Jian, 1985). However, Lim and Dominiy (1989) cited that replacing fish meal either partially or totally with less expensive plant proteins in practical diets of various warm water fish species had varying degrees of success. It is generally observed that plant proteins have a lower nutritive value than fish meal and high levels of inclusion of plant proteins usually result in reduced growth and feed efficiency. The ability of fish to utilize plant proteins also differs; results obtained by different researchers are sometimes contradictory. Despite the poor utilization of plant protein as compared to fish meal (for the presence of anti-nutritional factors or toxic substances, improper balance of essential nutrients, high fiber and carbohydrates content, decreased palatability and reduction of pellet quality), practically the plant proteins are being used to some extent in commercial warm water fish feeds.

Table (12): Chemical analysis (\% DM basis) of the fish body at the end of the experimental period as affected by level and source of dietary water hyacinth (WH).

\begin{tabular}{|c|c|c|c|c|c|c|c|c|}
\hline Treatment & \multicolumn{2}{|c|}{ Dry matter } & \multicolumn{2}{c|}{ Crude protein } & \multicolumn{2}{c|}{ Ether extract } & \multicolumn{2}{c|}{ Ash } \\
\hline $\begin{array}{c}\text { Source of } \\
\text { WH }\end{array}$ & $\begin{array}{c}\text { Clean } \\
\text { water }\end{array}$ & $\begin{array}{c}\text { Polluted } \\
\text { water }\end{array}$ & $\begin{array}{c}\text { Clean } \\
\text { water }\end{array}$ & $\begin{array}{c}\text { Polluted } \\
\text { water }\end{array}$ & $\begin{array}{c}\text { Clean } \\
\text { water }\end{array}$ & $\begin{array}{c}\text { Polluted } \\
\text { water }\end{array}$ & $\begin{array}{c}\text { Clean } \\
\text { water }\end{array}$ & $\begin{array}{c}\text { Polluted } \\
\text { water }\end{array}$ \\
\hline $\mathbf{T}_{\mathbf{1}}$ & 25.72 & 28.78 & $60.81^{\mathrm{abA}}$ & $58.83^{\mathrm{B}}$ & $19.27^{\mathrm{D}}$ & 20.77 & 19.63 & 19.60 \\
\hline $\mathbf{T}_{\mathbf{2}}$ & 28.01 & 25.85 & $60.17^{\mathrm{ab}}$ & 58.86 & $18.43^{\mathrm{b}}$ & 20.74 & 19.17 & 20.03 \\
\hline $\mathbf{T}_{\mathbf{3}}$ & 25.81 & 26.19 & $62.27^{\mathrm{aA}}$ & $58.17^{\mathrm{B}}$ & $20.35^{\mathrm{ab}}$ & 21.77 & 19.87 & 20.03 \\
\hline $\mathbf{T}_{\mathbf{4}}$ & 24.97 & 26.93 & $56.77^{\mathrm{C}}$ & $58.50^{\mathrm{Bb}}$ & $21.27^{\mathrm{a}}$ & 21.67 & $20.30-$ & 19.83 \\
\hline $\mathbf{T}_{\mathbf{5}}$ & 25.41 & 25.61 & $59.70^{\mathrm{b}}$ & $58.23^{\mathrm{B}}$ & $20.17^{\mathrm{ab}}$ & 21.63 & 20.03 & 20.14 \\
\hline $\mathbf{M S E}^{\star}$ & 0.48 & 0.52 & 0.55 & 0.19 & 0.32 & 0.21 & 0.30 & 0.20 \\
\hline
\end{tabular}

a, $b$ and $c$ means in the same rows bearing different letters differ significantly at 0.05 level.

$A$ and $B$ means in the same columns bearing different letters differ significantly at 0.05 level.

* Mean square of error from the analysis of variance. 
The facts of the negative relationship between $\mathrm{CP}$ and $\mathrm{EE}$ from one side and the between dry matter (DM) and CP on the other side were realized in this study. Also, there was a positive relationship between DM and EE contents. These relationships confirm those reported before since a negative relationship was noticed between $\mathrm{CP}$ and EE contents of fish body but a position relationship between $\mathrm{CP}$ and ash contents was recorded too (Abdelhamid et al., 2000; and El-Saidy and Gaber, 2002). There was a positive correlation between crude protein and fat contents of the fish, also Abdelhamid et al. (2004-a \& b and 2005-a \& b), Magouz et al. (2002-a \& b), El-Ebiary and Zaki (2003), Abdelhamid and El-Katan (2006-a \& b) and Abdelhamid et al. (2009) found a negative correlation between protein and fat contents of the fish.

\section{Economic evaluation:}

Elevating WH level reduced the feed intake, particularly from polluted source to about $30 \%$ of that consumed from clean-WH including diets (Table 13). Dietary inclusion of $\mathrm{WH}$ reduced the feed price gradually by increasing the level of WH substitution. Yet, total fish body gain decreased, especially by using $\mathrm{WH}$ from polluted source; so, the feed cost $/ \mathrm{Kg}$ bodyweight gain increased by increasing WH level of dietary inclusion but not be using the polluted WH because of the very low of feed intake. Similarly, Abdelhamid et al. (2006) found that same trend in their results.

Table (13): Data of economic evaluation of feeding process as affected by level and source of dietary water hyacinth (WH).

\begin{tabular}{|c|c|c|c|c|c|c|c|c|c|c|}
\hline \multirow{2}{*}{\begin{tabular}{|c|} 
Treatment \\
$\begin{array}{c}\text { Source of } \\
\text { WH }\end{array}$ \\
\end{tabular}} & \multicolumn{2}{|c|}{$\begin{array}{c}\text { Feed Intake } \\
(\mathrm{g})\end{array}$} & \multicolumn{2}{|c|}{$\begin{array}{l}\text { Cost (L.E) of } \\
\text { one Ton diet }\end{array}$} & \multicolumn{2}{|c|}{$\begin{array}{c}\text { Decrease in } \\
\text { feed cost (\%) }\end{array}$} & \multicolumn{2}{|c|}{$\begin{array}{l}\text { Total gain } \\
\text { (g/Fish }\end{array}$} & \multicolumn{2}{|c|}{$\begin{array}{c}\text { Feed } \\
\text { cost/gain* L.E) }\end{array}$} \\
\hline & Clean & Polluted & Clean & Polluted & Clean & Polluted & Clean & Polluted & Clean & Pollu \\
\hline & 111.40 & & & & - & & & & & \\
\hline$T_{2}$ & 131.08 & & 2625.4 & 2625.4 & 39.6 & 139.6 & 36.33 & & & \\
\hline$T_{3}$ & 124.34 & & 2425.9 & & & & & & & \\
\hline$T_{4}$ & 124.24 & & 2346.2 & 2346.2 & 418.8 & 418.8 & 42.33 & & 6.88 & 4.17 \\
\hline$T_{5}$ & 109.97 & 33.48 & 2206.8 & 2206.8 & 558.2 & 558.2 & 28.00 & 25.00 & 8.66 & 2.84 \\
\hline
\end{tabular}

${ }^{*}$ Feed cost $/ \mathrm{Kg}$ gain (L.E) = Feed intake (g) $\mathrm{x}$ cost (L.E) of one $\mathrm{Kg}$ feed / total gain (g).

Conclusively, it is not to recommend using water hyacinth from polluted water sources in feeding fish. In emergency cases only and in case of feed shortage, water hyacinth from non-polluted water sources could be used up to $30 \%$ not more as a substitute level in fish diets instead of soybean meal protein. In conclusion, the histological examination cleared no pathological lesions in liver and kidney or pathological effects on gills and the dorsal muscles when fish were fed diets in which protein of soybean meal was replaced by up to $20 \%$ water hyacinth from clean source or $10 \%$ water hyacinth from polluted source.

\section{REFERENCES}

Abdelhamid, A.M. (1994). Scientific Fundamentals for Fish Production and Management. An Arabic Textbook, Dar Al-Nashr for Egyptian Universities - Alwafaa Bookshop, Cairo, I.S.B.N. 977-5526-04-1, 658 p. (An Arabic Textbook). 
Abdelhamid, A.M. (1996). Field and Laboratorial Analysis in Animal Production. Dar Al-Nashr for Egyptian Universities, Cario, Deposi No. 11318/1996, 680 p. (Arabic Textbook).

Abdelhamid, A.M. (2009-a). Fundamentals of Fish Production and Culture. New Universal Office, Alexandria, I.S.B.N. 977-438-052-5, 393 p. (An Arabic Textbook).

Abdelhamid, A.M. (2009-b). Modern Approach in Aquaculture. New Universal Office, Alexandria, I.S.B.N. 977-438-053-3, 393 p. (An Arabic Textbook).

Abdelhamid, A.M. and El-Katan, M.S.A. (2006-a). A study on Nile tilapia fingerlings during wintering using dietary addition of Bio-Buds-2X. J. Agric. Sci. Mansoura Univ., 31: $5705-5711$.

Abdelhamid, A.M. and El-Katan, M.S.A. (2006-b). A study on Nile tilapia brooders during wintering by adding dietary fats or vitamins. J. Agric. Sci. Mansoura Univ., 31: $5689-5704$.

Abdelhamid, A.M. and Gabr, A.A. (1991-a). Utilization of water hyacinth hay in comparison with berseem hay as sole feeds by sheep with emphasis on its hazardous effects. J. Agric. Sci. Mansoura Univ., 16: $507-517$.

Abdelhamid, A.M. and Gabr, A.A. (1991-b). Evaluation of water hyacinth as a feed for ruminants. Arch. Anim. Nutr., Berlin, 41(7/8): $745-756$.

Abdelhamid, A.M., Khalil, F.F. and El-Zareef, A.A.M. (2000). Studies on iron in Egyptian freshwater fishes. 2- Effect of vitamin $C$ and/or vitamin $A$ supplementation on iron utilization by tilapia (Oreochromis niloticus) and catfish (Clarias lazera). J. Agric. Sci., Mansoura Univ., 25: 113 131.

Abdelhamid, A.M.; Mehrim, A.I.; Salem, M.F.I. and Yosuf, H.A.E. (2009). Allmale monosex Nile tilapia (Oreochromis niloticus), Pros and cons. Egypt. J. Basic Appl. Physiol., 8(1): $41-57$.

Abdelhamid, A.M., Salem, M.F.I. and Khalafalla, M.M.E. (2006). Substitution of soybean meal by waterhyacinth hay in diets of Nile tilapia (Oreochromis niloticus). The $2^{\text {nd }}$ Inter. Sci. Con. For Environment "Recent Environmental Problems and Social Sharement", 28-30 March, South Valley University. pp. 114 - 126 (Engormix.com Aquaculture Technical Articles, 2007, 6 p.).

Abdelhamid, A.M., Salem, M.F.I. and Tolan, A.E. (2004-a). Evaluation of sesame meal as a dietary protein source for Nile tilapia (Oreochromis niloticus) fingerlings. J. Agric. Sci. Mansoura Univ., 29 : 6887 - 6897.

Abdelhamid, A.M., Salem, M.F.I. and Tolan, A.E. (2004-b). Evaluation of mallow (Malva parviflora L.) plants as an alternative protein source for Nile tilapia (Oreochromis niloticus) fingerlings. J. Agric. Sci. Mansoura Univ., 29: 6899 - 6910.

Abdelhamid, A.M., Salem, M.F.I. and Tolan, A.E. (2005-a). Evaluation of linseed meal as feed ingredient in diets on growing Nile tilapia (Oreochromis niloticus). J. Agric. Res. Tanta Univ., 31(3): 385 - 402.

Abdelhamid, A.M., Salem, M.F.I. and Tolan, A.E. (2005-b). Utilization of black seed meal (Nigella sativa) in Nile tilapia (Oreochromis niloticus) diets. J. Agric. Res. Tanta Univ., 31(3): $403-419$. 


\section{Abdelhamid, A.M. et al.}

Abdelwareth, A.A. (2006). Fish Nutrition. Vol. 1 (An Arabic Textbook, AlAzhar Univ.). Deposition No. 8666/2006.

Alabaster, J.S. and Lioyed, R. (1982). Water Quality Criteria for Fresh Water Fish Second Edition. Bolter Work Scientific, London.

A.O.A.C. (1990). Official methods of analysis. $15^{\text {th }} \mathrm{Ed}$. Association of Official Agricultural Chemists. Benjamin Francklin Station,Washington. D.C., USA.

Bakeer, M.N. (2009). Trade and marketing of tilapia fish in Egypt. ASMAK, Fish World Magazine (Egyptian Fish Council), Oct.,No. 10, pp: 22 - 24.

Doumas, B.; Wabson, W. and Biggs, H. (1971). Albumin standards and measurement of serum with bromochresol green.Clin. Chem. Acto., 31: 87.

Duncan, D.B. (1955). Multiple range and multiple F-test. Biometrics, 11: 1-42.

El-Ebiary, E.H. and Zaki, M.A. (2003). Effect of supplementing active yeast to the diets on growth performance, nutrient utilization, whole body composition and blood consitituents of mono-sex tilapia (Oreochromis niloticus). Egypt. J. Aquat. Biol. \& Fish, 7(1): 127 - 139.

El-Ebiary, E.H.; Zaki, M.A. and Mabrook, H.A. (2004). Evaluation of plant protein concentrates in feeding Nile tilapia fry (Oreochromis niloticus). Egypt. J. Aquat. Biol. \& Fish., 8 (1): $1-17$.

El-Saidy, D.M.S. and Gaber, M.M.A. (2002). Intensive culture of Nile tilapia Oreochromis niloticus in concrete tanks in Egypt: Effect of stocking density and feeding levels on growth performance, production traits, feed conversion and body composition. Proc. $1^{\text {st }}$ Sc. Conf. Aqua., ElArish, $13-15$ Dec., pp.: $1-22$.

El-Sayed, A.F.M. (2006). Tilapia Culture. CABI Publishing, UK.

El-Sayed, A.M. (1999). Alternative dietary protein sources for farmed tilapia, Oreochromis spp. Aquaculture, 179: $149-168$.

El-Sayed, A.M. (2003). Effects of fermentation methods on the nutritive value of water hyacinth for Nile Tilapia Oreochromis niloticus (L.) fingerlings. Aquaculture, 218 (1-4): 471 - 478.

FAO, Food and Agriculture Organization of the United Nations (1997). Aquaculture Production Statistics 1986-1995. FAO Fish. Circ. No. 815, Rev. 9, Rome, Italy. 179 pp.

James, R.; Sampath, K., Pattu, V.J. and Devakiamma, G. (1992). Utilization of Eichhornia crassipes for the reduction of mercury toxicity on food transformation in Heteropneustes fossilis. J. of Aquacult. In the tropics, 7(2): $189-196$.

Jangaard, P.M.; Ackman, R.G. and Spois, A.J. (1967). Seasonal studies of the fatty acids composition of liver flesh, roe and milt lipid J. Fish Res. Biol. of Canada, 24: 613 - 627.

Jian, S. (1985). Training Manual - Integrated Fish Farming in China. Regional Lead Centre in China, Asian - Pacific Regional Research and Training Centre for Integrated Fish Farming, Wuxi, China.

Lim, C. and Dominiy, W. (1989). Utilization of plant proteins by warm water fish. Technical Bulletin, American Soybean Association, 12 P. 
Magouz, F.I.; Mohsen, M.K. and Abd El-Moniem, N.M. (2002-a). Utilization of different sources and levels of lipids in the diet of Nile tilapia (Oreochromis niloticus). Proc. $2^{\text {nd }}$ Conf. Foodborne Contamination and Egyptians' Health, 23 - 24 April, El-Mansoura, Egypt, pp.: 357 - 370.

Magouz, F.I.; Mohsen, M.K. and Gooda, A.H. (2002-b). Effect of including some biological feed additives in the diet on growth performance and feed efficiency of Nile tilapia (Oreochromis niloticus). Proc. $2^{\text {nd }}$ Conf. Foodborne Contamination and Egyptians' Health, 23 - 24 April, ElMansoura, Egypt, pp.: $329-339$.

McGowan, M.W.; Artiss, J.D., Standbergh, D.R. and Zak, B.A. (1983). Peroxidase-coupled method for colorimetric determination of serum triglycerides. Clin. Chem., 29: 538.

Merck, E. (1976). Labordiagnostik in der Tiermedizin. Diagnostica Merck, Darmstad, Deutschland.

NRC (1993). Nutrient requirements of fish. National Academy Press, Washington D.C.

Patton, F.G. and Grouch, S.R. (1977). Colorimetric determination of urea. Anal. Chem., 49: 464.

SAS (1996). SAS/STAT Guide for personal computer. SAS Inst. Cary, N. C.

Sivakami, S. and Ayyappan, S. (1991). Influence of different feeds on the body composition of silver carp Hypophthalmichthys molitrix Cultured in cages. National Symposium on New Hortzons in Freshwater Aquaculture, 22 - 25 January, 1991. Proceeoings, pp. $92-94$.

Tacon, A.G. (1997). Global trends in aquaculture and aquafeed production 1984- 1995. Int. Aquafeed Directory and Buyer's Guide 1987/1988, pp. 5-37.

Tietz, N.W. (1986). Textbook of clinical chemistry. W.B. Saunders, Philadelphia, USA, p: 1271.

Tietz, N.W. (1990). Clinical Guide to Laboratory Tests $2^{\text {nd }}$ ed. Philadelphia, USA.

Trinder, P. (1969). Ann. Clin. Biochem., 6: 24.

Tseng, W.Y. and K.L. Chan (1982). The reproductive biology of the rabbit fish in Hong Kong. J. World Maricul. Soc., 13: 313-321.

Varley, H. (1978). Practical Clinical Biochemistry. $4^{\text {th }}$ ed., Arnold-Heinemann Publishers (India).

Young, D.S. (1990). Effects of drugs on clinical laboratory tests. $3^{\text {rd }}$ ed. 3: 6.

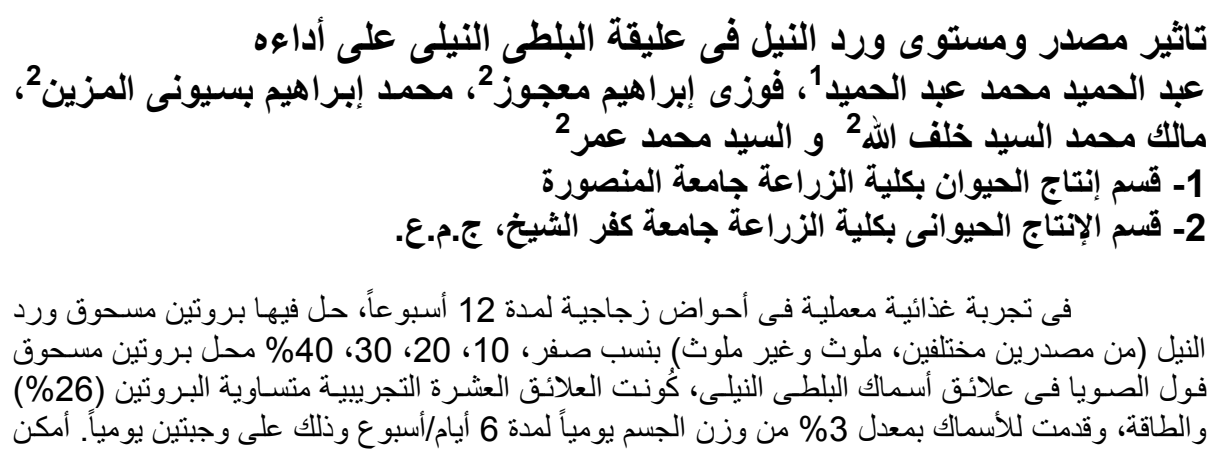




\section{Abdelhamid, A.M. et al.}

تلخيص النتائج فى أن خو اص جودة المياه لتربية الأسماك لم تتأتر بالمعاملات. زادت تركيز ات معظم العناصر

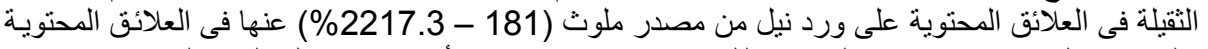

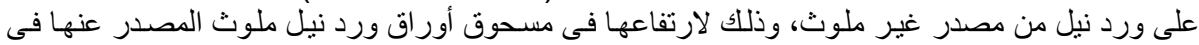

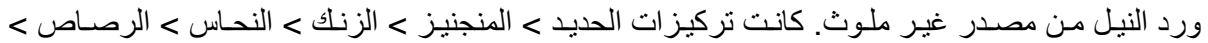

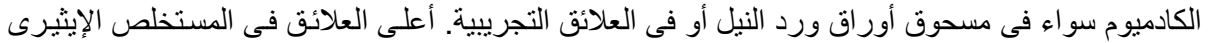

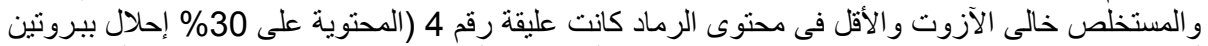

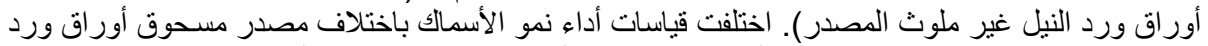

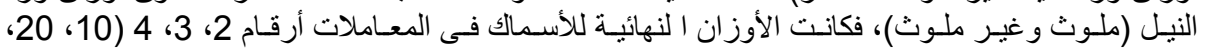

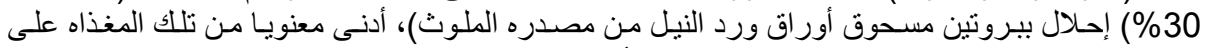

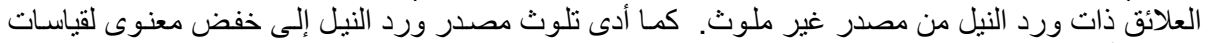

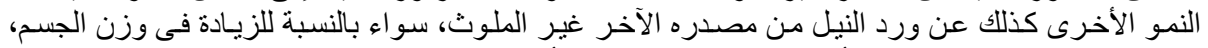

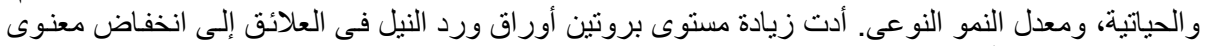

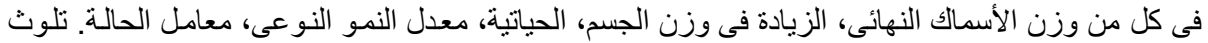

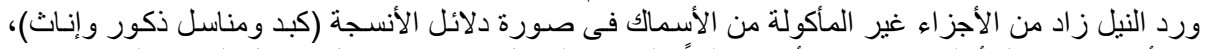

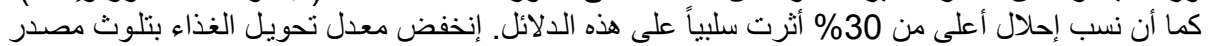

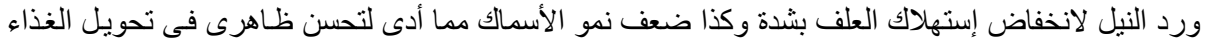

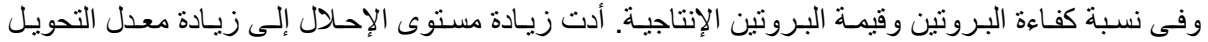

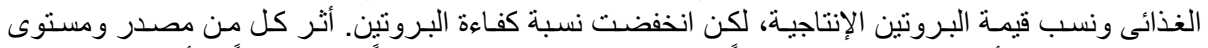

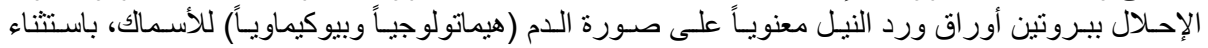

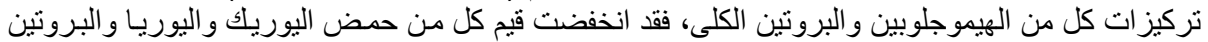

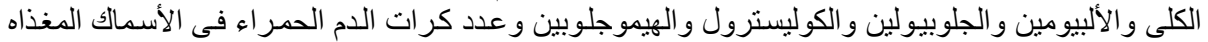

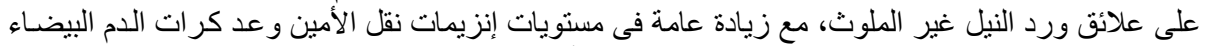

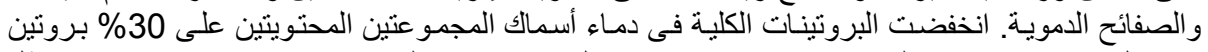

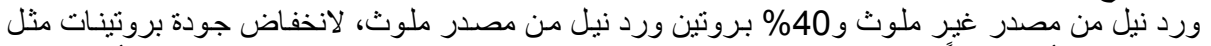

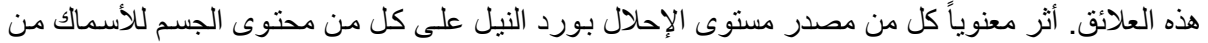

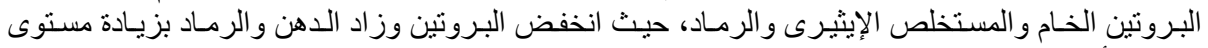

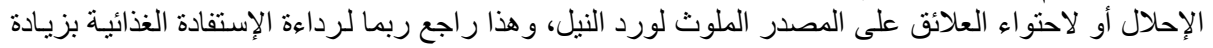

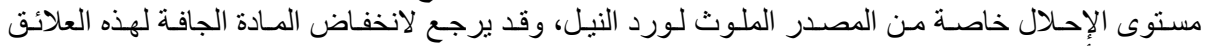

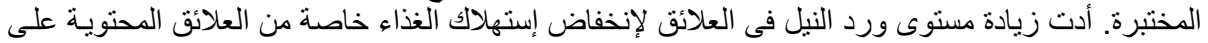

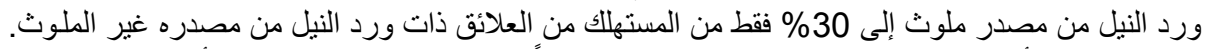

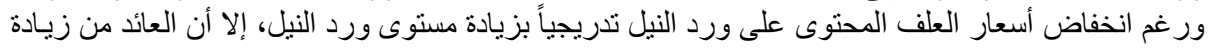

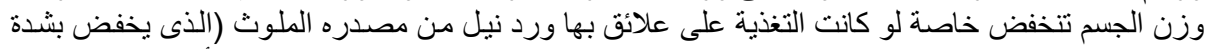

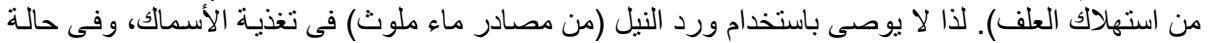

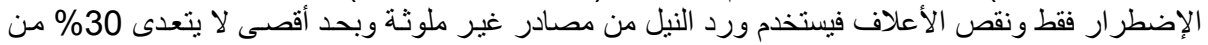
بروتين فول الصويا في العلائق.

كلية الزراعة - جامعة المنصورة كلية الزراعة - جامعة الفيوم
قام بتحكيم البحث محث

أ.د / محمد محمد الثناوي إسماعيل

أ.د / محمد محمد السعيد حسونة النينة إعيل 
Table (10): Data of blood hematological and biochemical parameters of the experimental fish at the end of experimental period as affected by the dietary level of water hyacinth (WH) from the clean source.

\begin{tabular}{|c|c|c|c|c|c|c|c|c|c|c|c|c|c|}
\hline $\mathbf{T}$ & $\begin{array}{l}\text { Jic } \\
\text { g/dl }\end{array}$ & $\begin{array}{l}\text { Urea } \\
\mathrm{mg} / \mathrm{dl}\end{array}$ & $\begin{array}{c}\text { T. Prot. } \\
\text { g/dl }\end{array}$ & $\begin{array}{l}\text { Albu } \\
\text { g/dl }\end{array}$ & $\begin{array}{l}\text { Glob } \\
\text { g/dl }\end{array}$ & $\begin{array}{c}\text { T. mg/dl } \\
\text { Lipid }\end{array}$ & $\begin{array}{c}\text { Cholost. } \\
\mathrm{Mg} / \mathrm{dl}\end{array}$ & AST $\mathbf{u} / \mathbf{I}$ & ALT u/I & $\begin{array}{c}\text { RBC } \\
10^{6}\end{array}$ & WBC & Plat. & $\mathrm{Hb} \mathrm{g/d}$ \\
\hline $\begin{array}{c}\mathrm{T}_{1} \\
\text { (Zero) }\end{array}$ & & $\begin{array}{l}1.20 \pm \\
0.20^{\mathrm{a}}\end{array}$ & $\begin{array}{l}2.93 \pm \\
0.03^{\text {N.S }}\end{array}$ & & & & & & & $\begin{array}{c}4.38 \pm \\
0.03^{\mathrm{a}}\end{array}$ & & & \\
\hline$T_{2}(10)$ & & 0.30 & $\begin{array}{c}2.65 \pm \\
0.25\end{array}$ & $\begin{array}{c}0.70 \pm \\
0.10^{b}\end{array}$ & & & & & $\begin{array}{c}61.50 \pm \\
0.50^{\mathrm{b}}\end{array}$ & & & 5.0 & \\
\hline & $\begin{array}{l}67 \pm \\
04^{\mathrm{bc}}\end{array}$ & $\begin{array}{c}11.15 \pm \\
0.25^{\mathrm{b}}\end{array}$ & $\begin{array}{c}2.90 \pm \\
0.10\end{array}$ & $\begin{array}{l}1.85 \pm \\
0.05^{\mathrm{a}}\end{array}$ & $\begin{array}{l}1.05 \pm \\
0.05^{\mathrm{b}}\end{array}$ & $\begin{array}{c}132.70 \pm \\
0.70^{\circ}\end{array}$ & $\begin{array}{c}159.00 \pm \\
1.00^{\mathrm{c}}\end{array}$ & $\begin{array}{c}80.00 \pm \\
1.00^{\mathrm{a}}\end{array}$ & $\begin{array}{c}77.50 \pm \\
0.50^{\mathrm{a}}\end{array}$ & $\begin{array}{l}3.45 \pm \\
0.05^{\mathrm{c}}\end{array}$ & $\begin{array}{c}2050.0 \pm \\
50.0^{\mathrm{a}}\end{array}$ & $0.50^{\mathrm{a}}$ & $\begin{array}{l}9.75 \pm \\
0.75^{\mathrm{b}}\end{array}$ \\
\hline $4(30)$ & $\begin{array}{c}0.55 \pm \\
0.05^{\mathrm{c}}\end{array}$ & $\begin{array}{c}13.20 \pm \\
0.30^{\mathrm{b}}\end{array}$ & $\begin{array}{c}2.05 \pm \\
0.05\end{array}$ & $\begin{array}{l}1.50 \pm \\
0.30^{\mathrm{a}}\end{array}$ & $\begin{array}{c}0.55 \pm \\
0.25^{\mathrm{b}}\end{array}$ & $\begin{array}{c}139.50 \pm \\
0.50^{\mathrm{b}}\end{array}$ & $\begin{array}{c}156.50 \pm \\
0.50^{c}\end{array}$ & $\begin{array}{c}76.50 \pm \\
2.50^{\mathrm{a}}\end{array}$ & $\begin{array}{c}77.00 \pm \\
1.00^{\mathrm{a}}\end{array}$ & $\begin{array}{c}3.85 \pm \\
0.05^{\mathrm{b}}\end{array}$ & $\begin{array}{c}1875.0 \pm \\
25.0^{\mathrm{b}}\end{array}$ & $\begin{array}{l}27.50 \pm \\
2.50^{\mathrm{a}}\end{array}$ & $\begin{array}{l}10.50 \pm \\
0.50^{\mathrm{ab}}\end{array}$ \\
\hline$T_{5}(40)$ & $\begin{array}{c}0.75 \pm \\
0.05^{\mathrm{b}}\end{array}$ & $\begin{array}{c}15.20 \pm \\
0.40^{\mathrm{a}}\end{array}$ & $\begin{array}{c}2.70 \pm \\
0.60\end{array}$ & $\begin{array}{c}0.766 \pm \\
0.14^{\mathrm{b}}\end{array}$ & $\begin{array}{l}1.89 \pm \\
0.41^{\mathrm{a}}\end{array}$ & $\begin{array}{c}147.20 \pm \\
0.00^{\mathrm{C}}\end{array}$ & $\begin{array}{c}160.00 \pm \\
0.00^{\mathrm{C}}\end{array}$ & $\begin{array}{c}64.00 \pm \\
0.00^{\mathrm{b}}\end{array}$ & $\begin{array}{c}64.00 \pm \\
0.00^{\mathrm{b}}\end{array}$ & $\begin{array}{l}4.25 \pm \\
0.05^{\mathrm{a}}\end{array}$ & $\begin{array}{c}1050.0 \pm \\
50.0^{d}\end{array}$ & $\begin{array}{c}122.50 \pm \\
2.50^{\mathrm{a}}\end{array}$ & $\begin{array}{c}10.75 \pm \\
0.25^{\mathrm{ab}}\end{array}$ \\
\hline Mean & $\begin{array}{c}0.73 \pm \\
0.05\end{array}$ & $\begin{array}{c}14.37 \pm \\
0.65\end{array}$ & $\begin{array}{c}2.65 \pm \\
0.14\end{array}$ & $\begin{array}{c}1.138 \pm \\
0.16\end{array}$ & $\begin{array}{c}1.50 \pm \\
0.21\end{array}$ & $\begin{array}{c}142.89 \pm \\
1.99\end{array}$ & $\begin{array}{c}174.10 \pm \\
6.49\end{array}$ & $\begin{array}{c}69.80 \pm \\
2.37\end{array}$ & $\begin{array}{c}69.80 \pm \\
2.37\end{array}$ & $\begin{array}{c}4.04 \pm \\
0.12\end{array}$ & $\begin{array}{c}1670.0 \pm \\
118.6\end{array}$ & $\begin{array}{c}120.10 \pm \\
3.65\end{array}$ & $\begin{array}{c}10.70 \pm \\
0.24\end{array}$ \\
\hline
\end{tabular}

$\mathrm{a}, \mathrm{b}, \mathrm{c}$ and $\mathrm{d}$ means in the same column bearing different letters differ significantly at 0.05 level.

N.S. not significant at $P>0.05$. 
Table (11): Data of blood hematological and biochemical parameters of the experimental fish at the end of experimental period as affected by the dietary level of water hyacinth (WH) from the polluted source.

\begin{tabular}{|c|c|c|c|c|c|c|c|c|c|c|c|c|c|}
\hline$T$ & $\begin{array}{l}\text { Uric } \\
\mathrm{mg} / \mathrm{dl}\end{array}$ & $\begin{array}{c}\text { Urea } \\
\mathrm{mg} / \mathrm{dl}\end{array}$ & $\begin{array}{c}\text { T. Prot. } \\
\text { g/dl }\end{array}$ & $\begin{array}{l}\text { Albu } \\
\text { g/dl }\end{array}$ & $\begin{array}{l}\text { Glob } \\
\text { g/dl }\end{array}$ & $\begin{array}{c}\text { T. mg/dl } \\
\text { Lipid }\end{array}$ & $\begin{array}{c}\text { Cholost. } \\
\text { Mg/dl }\end{array}$ & AST $u / l$ & ALT u/l & $\begin{array}{r}\text { RBC } \\
\times 10^{6}\end{array}$ & WBC & Plat. & $\mathrm{Hb} \mathrm{g} / \mathrm{dl}$ \\
\hline $\begin{array}{c}\mathrm{T}_{1} \\
\text { (Zero) }\end{array}$ & $\begin{array}{l}0.45 \pm \\
0.05^{\text {cd }}\end{array}$ & \begin{tabular}{|c|}
$12.75 \pm$ \\
$0.45^{\mathrm{b}}$
\end{tabular} & $\begin{array}{l}1.70 \pm \\
0.20^{\mathrm{ab}}\end{array}$ & $\begin{array}{l}0.88 \pm \\
0.08^{b}\end{array}$ & $\begin{array}{c}0.83 \pm \\
0.13^{\mathrm{a}}\end{array}$ & $\begin{array}{c}138.00 \pm \\
0.00^{\mathrm{bc}}\end{array}$ & $=\left[\begin{array}{c}222.50 \pm \\
2.50^{\mathrm{ab}}\end{array}\right.$ & $\begin{array}{c}76.50 \pm \\
1.50^{\mathrm{ab}}\end{array}$ & $\begin{array}{c}73.50 \pm \\
0.50^{\mathrm{ab}}\end{array}$ & $\begin{array}{l}4.28 \pm \\
0.03^{\mathrm{c}}\end{array}$ & $\begin{array}{r}1275.0 \pm \\
25.00^{\mathrm{c}}\end{array}$ & $\begin{array}{c}115.00 \pm \\
5.00^{\mathrm{bc}}\end{array}$ & $=\begin{array}{l}10.70 \pm \\
0.00^{\text {N.S }}\end{array}$ \\
\hline $\mathrm{T}_{2}(\mathbf{1 0})$ & $\begin{array}{l}0.82 \pm \\
0.02^{b}\end{array}$ & $\begin{array}{c}13.15 \pm \\
0.05^{\mathrm{b}}\end{array}$ & $\begin{array}{l}2.05 \pm \\
0.05^{\mathrm{a}}\end{array}$ & $\begin{array}{l}1.20 \pm \\
0.00^{\mathrm{a}}\end{array}$ & $\begin{array}{c}0.85 \pm \\
0.05^{\mathrm{a}}\end{array}$ & $\begin{array}{c}146.45 \pm \\
2.85^{\mathrm{a}}\end{array}$ & $=\begin{array}{c}232.50 \pm \\
7.50^{\mathrm{a}}\end{array}$ & $\begin{array}{c}65.00 \pm \\
1.00^{c}\end{array}$ & $\begin{array}{c}65.50 \pm \\
0.50^{c}\end{array}$ & $\begin{array}{l}4.48 \pm \\
0.03^{\mathrm{a}}\end{array}$ & $\begin{array}{c}1350.0 \pm \\
50.0^{\mathrm{bc}}\end{array}$ & $\begin{array}{c}104.00 \pm \\
2.00^{c}\end{array}$ & $=10.80 \pm$ \\
\hline$T_{3}(20)$ & $\begin{array}{l}0.65 \pm \\
0.05^{b c}\end{array}$ & $\begin{array}{c}15.15 \pm \\
0.35^{\mathrm{a}}\end{array}$ & $\begin{array}{l}1.90 \pm \\
0.06^{\mathrm{ab}}\end{array}$ & $\begin{array}{l}0.95 \pm \\
0.05^{\mathrm{b}}\end{array}$ & $\begin{array}{c}0.92 \pm \\
0.03^{\mathrm{a}}\end{array}$ & $\begin{array}{c}134.50 \pm \\
1.50^{c}\end{array}$ & $=\left(\begin{array}{c}240.00 \pm \\
1.00^{\mathrm{a}}\end{array}\right.$ & $\begin{array}{c}79.00 \pm \\
0.00^{\mathrm{a}}\end{array}$ & $\begin{array}{c}75.00 \pm \\
0.50^{\mathrm{a}}\end{array}$ & $\begin{array}{l}4.38 \pm \\
0.02^{b}\end{array}$ & $\begin{array}{c}1275.0_{ \pm}^{ \pm} \\
25.0^{c}\end{array}$ & $\begin{array}{c}105.00 \pm \\
0.50^{c}\end{array}$ & $=11.00 \pm$ \\
\hline $\mathrm{T}_{4}(\mathbf{3 0})$ & $\begin{array}{l}1.30 \pm \\
0.01^{a}\end{array}$ & $\begin{array}{c}12.05 \pm \\
0.05^{c}\end{array}$ & $\begin{array}{l}1.45 \pm \\
0.15^{b}\end{array}$ & $\begin{array}{l}0.85 \pm \\
0.05^{\mathrm{b}}\end{array}$ & $\begin{array}{l}0.55 \pm \\
0.05^{\mathrm{b}}\end{array}$ & $\begin{array}{c}144.15 \pm \\
2.55^{\mathrm{ab}}\end{array}$ & $=\begin{array}{c}237.50 \pm \\
2.50^{\mathrm{a}}\end{array}$ & $\begin{array}{c}77.50 \pm \\
0.50^{\mathrm{ab}}\end{array}$ & $\begin{array}{c}65.50 \pm \\
1.50^{c}\end{array}$ & $\begin{array}{l}4.33 \pm \\
0.03^{b c}\end{array}$ & $\begin{array}{c}1475.0 \pm \\
25.0^{\mathrm{b}}\end{array}$ & $\begin{array}{l}25.00 \pm \\
5.0^{\mathrm{ab}}\end{array}$ & $=11.40 \pm$ \\
\hline$T_{5}(40)$ & $\begin{array}{l}0.30 \pm \\
0.05^{\mathrm{d}}\end{array}$ & $\begin{array}{c}15.00 \pm \\
0.30^{\mathrm{a}}\end{array}$ & $\begin{array}{l}0.90 \pm \\
0.05^{c}\end{array}$ & $\begin{array}{l}0.38 \pm \\
0.03^{c}\end{array}$ & $\begin{array}{l}0.50 \pm \\
0.00^{b}\end{array}$ & $\begin{array}{c}134.50 \pm \\
1.50^{\mathrm{C}}\end{array}$ & $=\left(\begin{array}{c}209.00 \pm \\
9.00^{b}\end{array}\right.$ & $\begin{array}{c}75.50 \pm \\
0.50^{\mathrm{a}}\end{array}$ & $=\begin{array}{c}71.50 \pm \\
1.50^{\mathrm{a}}\end{array}$ & $\begin{array}{l}4.00 \pm \\
0.00^{d}\end{array}$ & $\begin{array}{c}1750.0 \pm \\
25.0^{\mathrm{a}}\end{array}$ & $\begin{array}{l}30.00 \pm \\
0.00^{\mathrm{a}}\end{array}$ & $=11.05 \pm$ \\
\hline Mean & $\begin{array}{c}0.70 \pm \\
0.12\end{array}$ & $\begin{array}{c}13.62 \pm \\
0.42\end{array}$ & $\begin{array}{c}1.60 \pm \\
0.14\end{array}$ & $\begin{array}{c}0.85 \pm \\
0.09\end{array}$ & $\begin{array}{l}0.73 \pm \\
0.06\end{array}$ & $\begin{array}{c}139.52 \pm \\
1.77\end{array}$ & $=\begin{array}{c}228.30 \pm \\
4.21\end{array}$ & $\begin{array}{c}74.70 \pm \\
1.69\end{array}$ & $=\begin{array}{c}70.20 \pm \\
1.36\end{array}$ & $\begin{array}{c}4.29 \pm \\
0.05\end{array}$ & $\begin{array}{c}1425.0 \pm \\
60.61\end{array}$ & $\begin{array}{c}115.90 \pm \\
3.61\end{array}$ & $=\begin{array}{c}10.99 \pm \\
0.15\end{array}$ \\
\hline
\end{tabular}

a, b, $c$ and $d$ means in the same column bearing different letters differ significantly at 0.05 level.

N.S. not significant at $P>0.05$. 